\title{
Becoming a language teacher: Constraints and negotiation in the emergence of new identities
}

\author{
David Block \\ ICREA-Universitat de Lleida, Spain \\ Article received 27 October 2014, accepted 14 February 2015, final version 8 June 2015 \\ DOI: http://dx.doi.org/10.5565/rev/jtl3.648
}

\begin{abstract}
Over the past three decades, identity has become a key construct in applied linguistics and there has been a great deal of research focussing on language learner identities. Meanwhile, less research has been devoted to language teacher identities, although there has been an increase in recent years. This paper ${ }^{1}$ makes a modest contribution to this growing literature. It examines how two Spanish nationals developed Spanish language teacher identities while attending a Postgraduate Certificate of Education (PGCE) course at a London university.
\end{abstract}

Keywords: language teacher identity, Spanish as a foreign language, teacher training, interviews

\section{Resumen}

Durante las últimas tres décadas, el concepto de la identidad se ha convertido en un constructo fundamental en la lingüística aplicada y por lo tanto, un gran número de estudios se han centrado en las identidades de los aprendices de idiomas. No obstante, ha habido menos investigación dedicada a las identidades de los docentes, aunque se ha producido un aumento en el número de estudios sobre ello en los últimos años. Este artículo hace una modesta contribución a esta creciente literatura. Examina cómo dos ciudadanas españolas desarrollan sus identidades como profesoras de español durante un curso Certificado de Postgrado de Educación (PGCE) en una universidad en Londres.

Palabras clave: identidad profesora de idiomas, Español como lengua extranjera, formación de profesores, entrevistas

\section{Resum}

Durant les últimes tres dècades, la identitat s'ha convertit en un constructe fonamental en la lingüística aplicada $i$ hi ha hagut una gran quantitat de recerca que s'ha centrat en les identitats dels aprenents d'idiomes. Mentrestant, hi ha hagut menys investigació dedicada a les identitats dels docents, tot i que s'ha produït un augment en els últims anys. Aquest article fa una modesta contribució a aquesta creixent literatura. Examina com dues ciutadanes espanyoles desenvolupen les seves identitats com a professores d'espanyol durant un curs Certificat de Postgrau d'Educació (PGCE) en una universitat a Londres.

Paraules clau: identitat professora d'idiomes, Espanyol com a llengua estrangera, formació de professors, entrevistes 


\section{Introduction}

In a suggestively titled article 'Do EFL teachers have careers?' Bill Johnston (1997) posed a question that had always intrigued me during the almost 18 years that I worked as an English language (hereafter EL) teacher in Barcelona, namely whether or not my colleagues and I merited the label 'professional'. In his article, Johnston described professions as worlds of work with particular defining characteristics, such as

control over entry ..., autonomy in terms of establishing and evaluating acceptable practices, representation by a powerful institutions (such as the American Medical Association), and a body of knowledge and skills that is recognized and highly regarded by the broader society. (Johnston, 1997, p. 702)

In 1990s Poland, Johnston found that EL teaching did not, in general, embody these characteristics of professionalism. The 17 teachers whom he interviewed, 12 Polish nationals and five expatriate native English speakers, for the most part described a world of precariousness with few prospects for personal and/or job-related self-fulfilment. Usually, the entry into EL teaching was by chance or due to external pressures. Job changes, when made, were more related to haphazard circumstances and pressures than the desire for a career move. The prospect of leaving teaching was ever present. Teachers often did not speak as teachers but as expert English speakers who 'really' were artists or authors, or some other media or art related self-identification. In short, missing in the teachers' stories were affiliations to the characteristics of professionalism mentioned above and any commitment to teaching was presented as a short-term phenomenon. And there was little if anything said about teaching as 'vocation'.

When I read this article, I was not surprised by the findings, although their application to the world of EL education in Barcelona that I knew was partial at best. It is worth noting that while EL education in Poland was still in its infancy at the time of Johnston's study, by the time I arrived in Barcelona in the late 1970s, it was already fairly well established in the state education sector. Thus English was already present in most secondary schools and was starting to appear in some primary schools. Importantly, it was on the way to the total dominance that it now experiences. Meanwhile, the private sector in which I worked was also growing. It was a highly stratified world, with low paying, poorly resourced neighbourhood academies at one extreme and well paying, well-resourced language centres at the other. And in this sector, qualifications and dedication varied considerably, although by the mid-1980s, there were many individuals who met Johnston's professionalism criteria. Nevertheless, there 
was also a sense- even among those who might be described as EL teaching professionalsthat EL teaching was a temporary phase in one's life and that a long-term career lay elsewhere. Of course for many, this career change never actually happened and in my case, it happened after many years, when I took up an academic post at the Institute of Education, University of London in autumn 1996.

This short discussion of EL teaching and professionalism serves as backdrop to the main topic of this paper- language teacher identity. Over the past three decades, identity has become a key construct in the social sciences and in applied linguistics there has been a great deal of research focussing on language learner identities. Meanwhile, somewhat less research has been devoted to language teacher identities, although there has been an increase in recent years (e.g. Clarke, 2008; Gray \& Morton, forthcoming; Harbon \& Maloney, 2013; Kanno \& Stuart, 2011; Menard Warwick, 2008, 2011; Miller, 2007, 2009; Phan Le Ha, 2008; Tsui, 2007, 2009, Varghese, Morgan, Johnston, \& Johnson, 2005). This research deals with language teacher identity in a variety of contexts distinguished by variables such as the teaching sector focussed on (primary education, secondary education, adult education) or the experience of the teachers involved (pre-service or in-service). It is not my intention here to review this growing body of research; rather, I propose to present a small part of some of my own research on language teacher identity. Picking up on the theme of the professional language teacher which emerges in the discussion above, I will discuss a study I carried out on the language teacher identities of two Spanish nationals attending a Postgraduate Certificate of Education (PGCE) course in London. Before examining some of the findings from this research, however, I first discuss identity as it has been conceptualised recently in the social sciences and applied linguistics, the research methodology employed and the two trainee Spanish teachers who are the focus of this paper.

\section{Identity}

The approach to identity adopted here is based broadly on work in social theory and sociology over the past 30 years (Giddens, 1991, and Weedon, 1997, being two foundational publications). This approach understands identities (in plural to indicate the multiplicity of the phenomenon) to be socio-culturally constructed, ongoing narratives, which develop and evolve across different spatio-temporal scales, ranging from the micro, local and immediate to the macro, global and long-term (Lemke, 2008). These socio-culturally constructed narratives 
are seen to emerge during individuals' engagements in activities and communication with others, with whom to varying degrees they share beliefs, motives and values, in communities of practice, where a community of practice is defined as 'an aggregate of people who come together around mutual engagement in an endeavour' (Eckert \& McConnell-Ginet, 1992, p. 464; see also Wenger, 1998). Alternatively, they may be seen as emergent in activity taking place in 'fields', where a field is understood to be

an independent social universe with its own laws of functioning, its specific relations of force, its dominants and its dominated, and so forth [: in short,] a particular social universe endowed with particular institutions and obeying specific laws. (Bourdieu, 1993, p. 163)

Interactions in communities of practice or fields of social activity can take place either face-to-face or in an electronically-mediated mode, with the latter becoming increasingly more prevalent. In addition, and consistent with the macro, global and long-term scale cited above, identity construction is seen as the negotiation of subject positions at the crossroads of the past, present and future. The interaction - and, ultimately, communication - through which this negotiation takes place is often primarily linguistic, in that language is often the key means through which people communicate. However, in the case of face-to-face communication, it is always multimodal, in that all such communication is about the deployment and uptake in interaction of semiotic resources (Jewitt, 2013). These resources range from the linguistic (syntax, morphology, phonology, lexis) to the prosodic (rhythm, stress, intonation) to the bodily (stance, gaze, gestures) to styling (clothing, hairstyle, jewellery, tattooing, piercing). Following Giddens's (1984) structuration theory, many identity researchers also take as axiomatic that individuals are shaped by ever-emergent and evolving social, cultural and historical structures, but at the same time - and indeed, in recursive fashion - they shape these same emergent and ever-evolving social, cultural and historical structures as their lives unfold. Among other things, negotiation means that such processes involve both self-ascription or self-positioning by individuals who in turn - and simultaneously - are ascribed identities and are positioned in particular ways by others with whom they come in contact. In this process, issues around perceived and invoked sameness and differences, and authenticity and inauthenticity, come into play. All of this means that the process of identity construction is potentially conflictive as it involves rupture and turbulences leading to change, or what I have described elsewhere as 'critical experiences':

[These] are periods of time during which prolonged contact with an L2 and a different cultural setting causes irreversible destabilization of the individual's sense of self. 
There is, in a sense, an element of before and after in critical experiences as the individual's sociohistorical, cultural and linguistic environment, once well defined and delimited, becomes relatively ill-defined and open-ended. (Block, 2002, pp. 4-5).

Finally, identities are related to different traditionally demographic categories such as ethnicity, race, nationality, migration, gender, disability, sexuality, religion, social class and language (Block, 2006, 2014 [2007]). To this list I would add a category which is important in the context of this paper, that is, what we might call an occupational identity, and specifically a language teacher identity. Such an identity may be defined in terms of how individuals, who both self-position and are positioned by others as teachers, affiliate to different aspects of teaching in their lives. Thus teacher identity is related to factors such as one's ongoing contacts with fellow teachers and students as well as the tasks that one engages in, which can be said to constitute teaching.

\section{Background}

In this paper I draw on data collected during research carried out between autumn 1999 and spring 2003. At the time, I was interested in how a high proportion of newly qualified Modern Foreign Languages (MFL) teachers in Britain were French, German and Spanish nationals, and individuals coming from countries with educational traditions and cultures different from those found in the UK. These trainee teachers would, like their British counterparts, need the sort of technical skills training which PGCE courses offered at the time; however, they would also need some acknowledgment of their non-British background and ideally, some discussion of comparative education and culture. Elsewhere (Block, 2001, 2005), I outline some of the problems which arise for teachers like these who have crossed nation-state, cultural and linguistic borders, drawing on an earlier study by Barry Jones (2000).

In a study based on interviews and the diaries of a cohort of French teachers, Jones identified six broad areas which were potentially problematic for non-British trainee teachers. These were: (1) language related problems (e.g. understanding acronyms and terminology, following meetings, understanding fellow teachers); (2) pedagogic problems (e.g. giving instructions, addressing student questions); (3) teacher-pupil relationships (understanding student humour and sarcasm); (4) procedure-related problems (e.g. understanding hierarchies in schools, disciplinary procedures, mentor relations, extracurricular activities, practical daily duties): (5) cultural problems (e.g. feeling 'foreign', dealing with differences between the home educational system and the British system); and (6) general living problems (e.g. 
accommodation, travel, medical care). Of course not all foreign trainee teachers in Britain have the same experience, as in many cases just one or two of the aforementioned problems will be salient. In addition, Jones's study and his conclusions are based on an acceptance of the status quo in British education, and especially, teaching training processes within it. There is therefore a will to make things easier for foreign trainee teachers, but little inclination to critique the more general state of play. In what follows, this paper will present a modest attempt to do just this, drawing on the comments of the two central informants.

\section{Methodology}

The purpose of interviews in my research was to engage trainee teachers in conversations about their experiences. These interviews may be characterised as 'in-depth' (Johnson, 2001), in that they were carried out with the intention of gaining deep understandings of the trainees' experiences as well as how they positioned themselves with reference to these experiences. They also may be termed 'responsive' (Rubin \& Rubin, 2005), in that as an interviewer I continuality adapted to the dynamics of the conversation and how I perceived the preferences of the trainees. However, as I note elsewhere (Block, 2000, 2015), it would be naive to think that in carrying out these interviews I was able to 'get inside the heads' of the teachers and in so doing, arrive at a complete knowledge and understanding of who they were. In other words, as an interviewer, I could never reasonably assume that my interviews were clean and easy information transfers providing me with windows on the minds of the teachers. My research therefore was not concerned with whether or not these individuals were telling the truth about what had happened to them. Nor was it about whether or not what they said about any number of topics was really what they thought. Rather, my position was always that their talk in interviews constituted enactments of discourses, understood as 'competing ways of giving meaning to the world and of organizing social institutions and processes' (Weedon, 1997: 34), in the making of subjectivities, understood as 'the conscious and unconscious thoughts and emotions of the individual, her sense of herself and her ways of understanding her relation in the world' (Weedon, 1997: 32). These subjectivities, in more enduring form, come to constitute identities, which are thus 'best understood as a limited and temporary fixing for the individual of a particular mode of subjectivity as apparently what one is ... [giving] individuals a singular sense of who they are and where they belong' (Weedon, 2004: 19). In interviews, what is actually said and how it is said may be classified as plausible or 
reasonable within that particular discourse. It is, therefore, a particular voice, which a particular speaker has adopted momentarily with a view to projecting a particular subject position. And the sum total of subject positions embodied by an individual at a given time may be seen to constitute her/his identity.

It is worth noting that the reference to plausibility in the previous paragraph is not idle and indeed, it is essential to my understanding of what people do when they participate in interviews. Plausibility moves us away from the 'anything goes' and 'nothing is real' traps of extreme relativism to the idea that the things that people say during interviews are the kinds of things that people in a particular sociohistorical context say when talking about a particular topic. It points to the fact that people could not live if in every moment the discourses through which they lived constantly changed. There is always some centre that must hold. This is not to say that at any one time, that centre is the entirety of who a person is; however, it is to say that people have neither the time nor the energy, neither the cognitive skills nor the sufficient wherewithal, to be making up a new life story every split second.

As for the analysis and interpretation of the interview data, I adopted for my study a form of thematic analysis (Guest, 2012). I identified salient themes, subthemes and narrative strands in the transcriptions of the interviews, which meant thoroughly immersing myself in the data via the reading and rereading of transcriptions. This thematic analysis worked in two directions. First, having read authors such as Jones (op cited) and spoken to PGCE instructors, I had an idea of the kinds of issues which trainee teachers might raise in their discussions of their experiences. In this sense, when I examined the data I was comparing and contrasting what these teachers said with what I knew about teachers with similar backgrounds who had passed through the PGCE process and ultimately a form of socialisation into British education. At the same time, I was not bound by what I already knew about trainee teachers in this context, and in the spirit of 'in-depth' (Johnson, 2001) and 'responsive' (Rubin \& Rubin, 2005) interviewing, I was attentive to themes, subthemes and narrative stands which had not emerged in previous research, as will become clear below.

\section{The trainee teachers}

The two trainee teachers discussed here have been assigned the pseudonyms Elena and Almudena. I interviewed them together on five occasions during the year that they were attending their PGCE course. These interviews were carried out in Spanish and selected parts 
of them were transcribed. All translations were carried out by the author and then checked with a professional Spanish English translator. Transcription conventions for all excerpts are provided in Appendix 1. The original (Spanish) versions of all cited interview excerpts are provided in Appendix 2.

The first trainee teacher, Elena, was born and raised in Bilbao, where she studied at the French School until the age of 16. While completing her undergraduate studies, she taught Spanish to foreign students at her university, and later, during a one-year stint as a research assistant at a German university, she taught Spanish to German students. At the time of our first contact, Elena had been living in the UK for two years. Initially, she was a student at Cambridge University, in the Faculty of Classics, where she taught Greek and Latin and was responsible for undergraduate tutorial groups. Elena thus came to her PGCE course with a strong academic background and she could have gone onto to $\mathrm{MA}$ and $\mathrm{PhD}$ study. Nevertheless, it seems that she had grown tired of the abstract topics she was encountering in the study of linguistics. Longing to do something both practical and useful, in her second year at Cambridge, she decided that she did not want to do a $\mathrm{PhD}$ in linguistics after all. This decision led her to do what she termed 'voluntary work' in schools, teaching Spanish, French, German as well as Greek history. On how she made the transition from the more academic environment of Cambridge to the PGCE, she had the following to say:

\section{Excerpt 1}

at the end of my first year in Cambridge I decided /or more than decided /I realised that I didn't want to carry on doing research in linguistics/I didn't want to go on to do a $\mathrm{PhD}$ in the use of the imperative or the pragmatics of expressions derived from Greek/because it just seemed too abstract/too absolutely not related to anything/I just thought I was digging a really big hole/and I was going to get into it and never get out of it/and so (.5) I started thinking about all the things I would like to do/because I had always enjoyed the teaching of languages a lot/because I had always been a student in language classes (.5) of every language since the age of four/I really knew what I liked in the classroom/and I had lots of ideas and I really enjoyed that/so well/ I decided the next step necessarily had to be a PGCE (.5) I really missed that practical experience/(Elena 28/9/99)

The second trainee teacher, Almudena, was born and raised in a small village in the province of Burgos in Castilla y León. Initially, she attended the village school with a total of 12 students, but when she was nine, her parents decided to send her to a boarding school run by nuns in the city of Burgos. She later studied tourist management at a private university in Madrid, before moving to London in 1992, ostensibly to prepare for the Cambridge First 
Certificate exam. However, as Almudena explained, 'six months became seven years' as she was drawn in by London's cosmopolitanism, a personal relationship and finally, the realisation that her friends and life were in London. She also studied during this time, completing an undergraduate degree in linguistics at the School of Oriental and African Studies in 1998.

When asked why she was doing the PGCE, she said that after teaching adults for five years off and on, she was ready for the 'challenge' of teaching in a secondary school. She deemed the PGCE course to be the best way to find out how best to teach in this context. As regards her long-term prospects as a teacher, she echoed the teachers in Johnston's study (1997) when she said that she wanted to become a teacher now, but that in the long term, she would do something else (she was a keen photographer). Nevertheless, she did express enthusiasm when talking about how she felt when teaching:

\section{Excerpt 2:}

Out of the many jobs that I've tried / teaching is the one that makes me feel great/ you know / I just finish the class and I go / I can't believe I'm getting paid for this / I'm having fun / and I love working with people / and I'm not a person who could happily be behind a desk / I need to mix with people. (Almudena, 28/9/99)

\section{Becoming a Spanish teacher in London: Procedural and cultural problems}

If we are to judge by what they said in their initial interview with me, both Elena and Almudena began their PGCE course positively predisposed to learning as much as they could about being a Spanish teacher in the UK context. However, they soon encountered problems, as described by Jones (see above). In this section, I will explore some of the experiences described to me by Elena and Almudena as procedural and cultural problems which they had to negotiate their ways through on the way to developing a Spanish teacher identity. Space does not allow a truly in-depth treatment of everything Elena and Almudena talked about in their interviews, which means that the discussion which follows is necessarily partial.

Three weeks into the PGCE course, Elena and Almudena had been on school placements in London secondary schools, where they had observed teachers and begun their practice teaching. When asked how they felt about this experience, they both responded positively. At the same time, the two women had grasped two negative aspects of a teacher's life in Britain: the bureaucracy and creeping managerialism which had taken hold (Block \& Gray, 2016; Block, Gray and Holborow, 2012), two issues somewhat outside the list compiled 
by Jones (op cited). One aspect of this bureaucracy was the requirement that trainees provide 'evidence' of their learning about teaching. Elena spoke about this issue as follows:

\section{Excerpt 3}

I spent a whole day last week writing the evidence /which consists of seven sentences stating I realised this and bla bla bla/but because it's evidence based/actually (.5) I could very well not have done these things and written it anyway (.5) they're asking you to create the evidence out of nothing (.5) but it's completely possible/because it's such a long list/and I told my mentor that/and he said/well do it/if you think by the end of the year you haven't produced evidence for everything/just fake it. (Elena, 28/9/99)

Elena thus explains how she felt overwhelmed with the requirement to document her learning in ways which had no face validity for her, given the ease with which the 'evidence' could be fabricated. Her view was echoed by Almudena, who admitted that she had already abandoned such bookkeeping exercises and would not return to them unless she was required to do so. Later in the same interview, another apparent absurdity arose, as the following exchange occurred:

Excerpt 4: NB: $E=$ Elena $\quad \mathrm{D}=$ David Block $\quad \mathrm{A}=$ Almudena

E: now there are posters!/ \{said with false earnestness\}

D: what kind?/

A: motivational posters/ $\{$ said in dramatic tone $\}$

E: posters like $(.5)$ the man hanging off a cliff= extending arms upwards as if hanging

$\mathrm{A}:=$ no two dolphins $!=$ making a sweeping motion with her right hand

$\mathrm{E}:=$ and a sentence that says you can do $\mathrm{it}=$ \{speaking hurriedly with false earnestness $\}$

A: =no group work leads to success/or something like that / \{speaking hurriedly with false earnestness $\}$

E: they're done by companies [that

A: $\quad$ [I kept one to send to my friends [in Spain]/

(Elena and Almudena, 28/9/99)

The focus of this short exchange is motivational posters, which began to be used in business environments in the US in the 1970s as a way of preparing workers psychologically for whatever tasks they might encounter in the workplace. Here we see their intrusion into a domain in which they would have been foreign in Britain until the 1990s- schools. Motivational posters generally centre on a picture of someone in an adverse situation, often an extreme one (Elena's example of the man hanging from a cliff), although some present happy scenes from the natural world (Almudena's example of dolphins swimming in the sea). 
Whatever their orientation, such posters have become the object of much derision on internet sites, where they are often ridiculed as silly and naïve.

Following what I said above about multimodal communication, I have reproduced in the transcription not only what was said but how it was said and inflected with a view to conveying to the reader the sarcasm coming from the two women as they ridicule the use of motivational posters in the schools where they have had placements. Extremely critical of these posters, Elena and Almudena embody their disdain in their voice inflections and bodily movements, feigning dramatic and earnest tones and exaggerating their physical gestures (e.g. Elena imitating the man hanging from a cliff and Almudena's sweeping hand movement when talking about dolphins). The code switching into English might be interpreted as further distancing from the posters as the two women do not bother to translate into Spanish the term 'motivational' and with the exception of Almudena's 'dos delfines', the slogans on the posters are all cited in the original English: 'the man hanging off a cliff'; 'you can do it'; and 'group work leads to success'.

As I note elsewhere (Block, 2010), the two women's expressed resistance to motivational posters, and indeed their ridiculing of the very idea that they are present in schools, is about the clashing of education cultures. Thus in the ongoing construction of their identity narratives in the field of education, as 'an independent social universe with its own laws of functioning' (Bourdieu, 1993: 163), there is moment of conflict and turbulence. On a larger scale, Elena and Almudena are resisting what is means to be a teacher in $21^{\text {st }}$ century Britain, in particular how teaching is framed as scientific activity which can be broken down into discrete components (Block \& Gray, 2016; Block, Gray and Holborow, 2012) and more importantly the idea that teachers can be pushed to work harder through motivational techniques adopted from the world of business. Elena and Almudena seem all too aware that the posters are an example of the encroachment of marketing and business-like principles on the domain of teaching and they do not accept it.

Another problem for Elena and Almudena was what they perceived during their school placements as low expectations as regards students deemed to be 'weak'. They were very critical of what they saw as particular interpretation of 'learner-centeredness', which too often converted catering to individual needs into making assigned work as easy as possible. For Elena and Almudena, learning involved a lot of hard graft and it was the teacher's job to make 
sure that students at least made an effort to engage with difficult tasks. Elena describes what she observed at one of the secondary schools where she did teaching practice as follows:

\section{Excerpt 5}

I think they have the erroneous theory / that you shouldn't explain it [grammar] to the weakest students, / that you have to teach everything to them as items of vocabulary / but actually the weakest students / the ones who have learning difficulties / the first problem they have is with their memory / so if you explain things to them without any structure / it's much more difficult for them / you're not doing them any favour taking the structure away / the thing is you have to explain it to them in a different way / (Elena, 10/11/99)

Echoing this view, Almudena explained in a later interview her view that the comprehensive schools which she had visited seemed to function as dumping grounds for less able students:

\section{Excerpt 6}

kids actually can learn a lot more than they are taught in comprehensives/I don't think that the kids in comprehensive are dumb/ (Almudena, 13/6/00)

The problem identified by Elena and Almudena is both a procedural one and a cultural one. It is procedural in that their way of dealing with students is different from how the PGCE course teaches them to deal with students. At a deeper level, it is cultural in that both Elena's French style education and Elena's experiences in a variety of Spanish schools would have imbued them with what Martin McLean (1995) long ago described as 'rationalist' tradition in education, in which 'learning and teaching ... [are] associated with a systematic view of the physical world ... [and c]apacities for logic, deduction and abstraction together with systematization and synthesis should be developed to make sense of this universe and ultimately to change it' (McLean, 1995, p. 30). In such a tradition, there is little space for what Elena and Almudena saw as 'spoon feeding students'. In the rationalist approach individual differences are marginalised in favour of the universalist view that all can achieve if they work hard enough.

All of this is fine, except that the two women found themselves immersed in an educational system based on what McLean describes as the 'humanist' tradition. In such a system, the starting point is 
the human character and its potential rather than the structure of the physical universe ... [, and t]he central aim is to develop qualities among the young, that will serve them in later life, through acquaintance with great achievements of individuals of past generations. (McLean,1995, p. 22)

As with the previous problem, Elena and Almudena once again find themselves in a point of conflict brought on by the lack of alignment between their past experience as students in Spain and their current experience as teachers in London. To resolve this issue, the two women needed to negotiate a way through, between and around what in effect are educational discourses in conflict. It is worth noting that this resolution did indeed occur as Elena and Almudena completed their PGCE course and then took up posts in secondary schools in Greater London secondary schools. Once in post, the two explained to me that they were able to offer the best of two worlds- stricter control over content, which was perhaps derived from their experiences in Spain, combined with the more individualised and nurturing approach of British education. In other words, they developed something of a synthesis of McLean's rationalism and humanism. And in so doing they emerged as British Spanish teachers, an identity inscription which did not form part of how they positioned themselves just a few years earlier in their lives.

\section{Conclusion}

In the latter part of this paper, I have provided a fleeting snapshot of Elena's and Almudena's experiences of adapting to British education and their emergent occupational identities as Spanish teachers in London secondary schools. As stated above, in their interviews, the two trainees tended to present problems in terms of procedural and cultural dimensions. This is not to say that they never spoke about problems falling into Jones's other categories- they did. Thus there were occasions where they made comments about their English language ability with regard to communicating across a range of work-based contexts; pedagogical practices which they felt that they got wrong (e.g. giving clear instructions); and their dealings with students (discipline was an issue raised at one time or another by all of the trainees participating in the larger study). In addition, because the interviews were 'in-depth' and 'responsive', as explained previously, there was ample talk in them about life in general and living as a 'foreigner' in Britain (Jones's sixth dimension). Above all, Elena and Almudena often engaged in what I would call insightful critique of the educational field and the practices therein, which they encountered and were immersed in on a day-to-day basis. 
In these interviews, we see how language teacher identities are constructed in the stories told and accounts provided by the two trainees. As I noted above, I cannot know if these stories and accounts are completely true but I can judge them as plausible in that they are the kinds of things that teachers experience and talk about and therefore they have a certain air of authenticity about them. Drawing on often conflicting discourses of educational procedure and culture, Elena and Almudena construct subjectivities critical of accepted practices regarding how students and teachers are positioned and treated: over-nurturing student centeredness for students and managerialism for teachers. And these subjectivities, along with others which have not been discussed here, come to constitute larger language teacher identities, that is, who Elena and Almudena are as teachers. During the PGCE and beyond, when they took up posts in Greater London schools, they charted a course spanning their past and present experience and the kind of teachers they imagined themselves to be in the future. And, following Giddens (1984), they acted as agents constrained by structures in the form of practices constituting British educational culture, while subtly and gradually altering those structures through their activity.

The process of becoming a teacher in a cultural setting that is different from the one in which one was educated, is a long and hard road of adaptation and re-making of who one is. And certainly the process from relative beginner teacher to relative experienced teacher will always be disruptive to one's sense of self and therefore constitute a critical experience (Block, 2002). Indeed, the move into any new occupational identity is normally marked by many ups and downs as knowledge acquired both formally and empirically mediates a transition from outsider (non-teacher) to insider (teacher) in the community of practice in question.

\section{References}

Block, D. (2000). Problematizing interview data: Voices in the mind's machine? TESOL Quarterly, 34 (4), 757-763. DOI: 10.2307/3587788

Block, D. (2001). Foreign nationals on PGCE in modern languages course: Issues in national identity construction, European Journal of Teacher Education, 24 (3), 291-312. DOI: 10.1080/02619760220128860

Block, D. (2002). Destabilized identities across language and cultural borders: Japanese and Taiwanese experiences, Hong Kong Journal of Applied Linguistics, 7 (2), 1 19.

Block, D. (2005). Convergence and resistance in the construction of personal and professional identities: Four French modern language teachers in London. In S. A. Canagrajah (ed.), Reclaiming the local in language policy and practice (pp. 167- 
96). Mahwah NJ: Lawrence Erlbaum.

Block, D. (2006). Multilingual identities in a global city: London stories, London: Palgrave.

Block, D. (2007). Second language identities, London: Continuum.

Block, D. (2010). Engaging with human sociality: Thoughts on communication and embodiment. Applied Linguistics Review, 1 (1), 45-56. DOI: $10.1515 / 9783110222654.45$

Block, D. (2015). Researching language and identity. In B. Paltridge \& A. Phakiti (eds), Research methods in applied linguistics, 2nd edition (pp. 527-540). London: Bloomsbury.

Block, D., \& Gray, J. (tbp 2016). 'Just go away and do it and you get marks': The degradation of language teaching in neoliberal times. Multilingual and Multicultural Development, 36 (1).

Block, D., Gray, J., \& Holborow, M. (2012). Neoliberalism and applied linguistics. London: Routledge.

Bourdieu, P. (1993). The field of cultural production: Essays on art and literature. Cambridge: Polity.

Clarke, M. (2008). Language teacher identities. Bristol: Multilingual Matters.

Eckert. P., \& McConnell-Ginet, S. (1992). Think practically and act locally: Language and gender as community-based practice. Annual Review of Anthropology, 21: 461490. DOI: $10.1146 /$ annurev.an.21.100192.002333

Giddens, A. (1984). The constitution of society: Outline of the theory of structuration. Cambridge: Polity.

Giddens, A. (1991). Modernity and self-identity: Self and society in the late modern age. Cambridge: Polity.

Gray, J. \& Morton, T. (forthcoming). Social Interaction and ELT Teacher Identity. Edinburgh: Edinburgh University Press.

Guest, G. (2012). Applied thematic analysis. Thousand Oaks, California: Sage.

Harbon, L. \& Maloney, R. (eds.). (2013). Language teachers' narratives of practice. Newcastle. Cambridge Scholars.

Jewitt, C. (ed.). (2013). The Routledge handbook of multimodal analysis, 2nd Edition. London: Routledge.

Johnson, J. M (2001). In-depth interviewing. In J. F. Gubrium, J. A. Holstein (eds.) The handbook of interview research (pp. 103-119). London: Sage.

Johnston, B. (1997). Do EFL teachers have careers?, TESOL Quarterly, 31, 681-712. DOI: $10.2307 / 3587756$

Jones, B. (2000). The Post Graduate Certificate in Education (PGCE) and the Maitrise Français Langue Etrangère (FLE): An account of student teachers' experience. Paper given at the National conference for teacher trainers in MFL, Trinity and All Saints Comenius Centre, Leeds, 8-10 September 2000.

Kanno, Y., \& Stuart, C. (2011). Second language teacher: Identities-in-practice. Modern Language Journal, 95 (2), 236-252. DOI: 10.1111/j.1540-4781.2011.01178.x

Lemke, J. (2008). Identity, development, and desire: Critical questions. In C. R. CaldasCoulthard \& R. Iedema (eds.). Identity trouble: Critical discourse and contested identities (pp. 17-42). London: Palgrave.

McLean, M. (1995). Educational traditions compared. London: David Fulton.

Menard-Warwick, J. (2008). The cultural and intercultural identities of transnational English teachers: Two case studies from the Americas, TESOL Quarterly, 42, 617- 
640. DOI: 10.1002/j.1545-7249.2008.tb00151.x

Menard-Warwick, J. (2011). Chilean English teacher identity and popular culture: three generations. International Journal of Bilingual Education and Bilingualism, 14, 261-277. DOI: 10.1080/13670051003797466

Miller, J. (2007). Identity construction in teacher education. In Zhu Hua, P. Seedhouse, Li Wei V. Cook (eds.). Language learning and teaching as social interaction (pp. 148-162). London: Palgrave.

Miller, J. (2009). Teacher identity. In A. Burns \& J. Richards (eds.). Cambridge guide to second language teacher education (pp. 172-181). Cambridge: Cambridge University.

Phan Le Ha (2008). Teaching English as an international language: Identity, resistance and negotiation. Bristol: Multilingual Matters.

Rubin, H. J. \& Rubin, I. S. (2005). Qualitative interviewing: The art of hearing data, $2^{\text {nd }}$ edition. London: Sage.

Tsui, A. (2007). Complexities of identity formation: A narrative inquiry of an EFL teacher. TESOL Quarterly, 41: 657-680. DOI: $10.1002 / \mathrm{j} .1545-$ 7249.2007.tb00098.x

Tsui, A. (2009). Distinctive qualities of expert teachers, Teachers and Teaching: Theory and Practice, 15, 421-439. DOI: 10.1080/13540600903057179

Varghese, M., Morgan, B., Johnston, B. \& Johnson, K. A. (2005). Theorizing language teacher identity: Three perspectives and beyond. Journal of Language, Identity \& Education, 4 (1): 21-44. DOI: 10.1207/s15327701jlie0401_2

Weedon, C. (1997). Feminist practice and poststructuralist theory, 2nd edition. Oxford: Blackwell.

Weedon, C. (2004). Identity and culture: Narratives of difference and belonging. Buckingham, UK: Open University Press.

Wenger, E. (1998). Communities of practice: Learning, meaning, and identity. Cambridge: Cambridge University Press.

${ }^{1}$ This paper is based on a plenary address given at the Colóquio Internacional, Educação em Linguas, Universidade de Porto, 4 November 2011.

\section{Appendix 1: Transcription conventions}

/

?

$[\mathrm{xxx}$

[zzz

$=$

italics

$!$ indicates the minimal but clear pause between phrases/sentences in normally paced speech.

indicates pause of half a second

indicates pause of one second

indicates rising intonation (including questions)

indicates overlapping speech

indicates that the utterance latches with (i.e. occurs seamlessly after) the next utterance

indicates words that were produced in English in the original version indicates raised intonation, exclamation 
$\{\mathrm{xxx}\}$

comments describing aspects of extra-linguistic communcation, such as voice inflection, laughter, facial expressions, gaze, hand movements, etc.

\section{Appendix 2: Interview excerpts in original Spanish versions}

\section{Excerpt 1}

al final de mi primer año en Cambridge decidí/o más que decidir /me di cuenta de que no quería seguir investigando la lingüística/no quería seguir hasta hacer un $P h D$ en el uso imperativo o la pragmática de las expresiones derivadas del Griego/porque me parecía demasiado abstracto/demasiado absolutamente no relacionado con nada/solo pensaba que me estaba cavando un agujero realmente muy grande/y que me iba a meter ahí y jamás salir de él/y entonces (.5) empecé a pensar en todas las cosas que quisiera hacer/porque siempre me había disfrutado mucho enseñando los idiomas / porque siempre había sido un estudiante en clases de idiomas (.5) de todos los idiomas desde los cuatro anos/sabia realmente lo que me gustaba en el aula/y tenia muchas ideas y disfrutaba mucho con aquello/entonces pues /decidí que el próximo paso necesariamente había de ser el PGCE (.5) realmente echaba de menos aquella experiencia práctica/ (Elena 28/9/99)

\section{Excerpt 2}

De los muchos trabajos que he probado/enseñar es el que me hacer sentir estupenda/sabes/acabo la clase y voy/I can't believe I'm getting paid for this/I'm having fun/y me encanta trabajar con la gentely no soy una persona que podría fácilmente estar detrás de una mesa/necesito mezclarme con la gente/ (Almudena, 28/9/99)

\section{Excerpt 3}

yo me pasé un día entero la semana pasada escribiendo la evidence/que son cosas de siete frases de decir today I realised this and bla bla bla/pero como está evidence based/en realidad (.5) podría perfectamente no haber hecho estas cosas y escribirlo igual (.5) te están pidiendo que crees la evidencia de la nada (.5) pero es totalmente posible/porque es una lista tan brutal/y lo dije a mi mentor/y me dijo/well do it/if you think by the end of the year you haven't produced evidence for everything/just fake it/ (Elena, 28/9/99)

\section{Excerpt 4}

E: \{speaking with false earnestness\} jahora hay posters!/

D: ¿de que clase?/

A: \{speaking in an exaggeratedly dramatic tone\} motivational posters/

E: posters como (.5) \{extending arms upwards as if hanging the man hanging off a cliff=

$\mathrm{A}:=\{$ making a sweeping motion with her right hand $\}$ no $¡$ dos delfines!=

$\mathrm{E}:=\{$ speaking hurriedly with false earnestness $\}$ y una frase que dice you can do it=

$\mathrm{A}:=\{$ speaking hurriedly with false earnestness $\}$ no group work leads to success/o algo así/

$\mathrm{E}$ : los hacen empresas [que

A: [me guardé uno para enviar a mis amigos [en España]/ 


\section{Excerpt 5}

yo creo que tienen la teoría errónea / de que a los más débiles no hay que explicarsela / que hay que enseñarles todo como items of vocabulary / pero precisamente los más débiles / los que tienen learning difficulties / el primer problema que tienen es de memoria / entonces si les explicas las cosas sin ninguna estructura / es mucho más difícil para ellos / no les estás haciendo ningun favor al quitarles la estructura / lo que pasa es que hay que explicarlo de otra manera / (Elena, 10/11/99)

\section{Excerpt 6}

los niños realmente pueden aprender mucho más de lo que se les enseñan en comprehensives/no me creo que los niños de comprehensives son muy tontos/ (Almudena,13/6/00)

\section{Author information:}

David Block is ICREA Research Professor in Sociolinguistics at the Universitat de Lleida. His main interests are the impact of political economic, sociological, anthropological and geographical phenomena on multimodal practices of all kinds, including social movements, multiculturalism, bi/multilingualism and the acquisition and use of languages. Over the past 25 years, he has published 6 books, including Multilingual Identities in a Global City: London Stories (2006) and Social Class in Applied Linguistics (2014), and numerous journal articles and book chapters on a variety of topics, including globalization, migration, multiculturalism, multilingualism, identity and second language teaching and learning. In his more recent work he has focussed specifically on neoliberalism as the dominant ideology in contemporary societies and social class as a key dimension of identity. He is Fellow of the Academy of the Social Sciences (UK) and editor of the Routledge book series Language, society and political economy.

Email: dblock@dal.udl.cat

To cite this article:

Block, D. (2015). Becoming a language teacher: Constraints and negotiation in the emergence of new identities. Bellaterra Journal of Teaching \& Learning Language \& Literature, 8(3), 9-26. DOI: http://dx.doi.org/10.5565/rev/jtl3.648

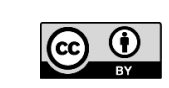

